\title{
OHIO WESLEYAN UNIVERSITY NATURAL RADIOCARBON MEASUREMENTS I
}

\author{
J. GORDON OGDEN, III and RUTH J. HAY
}

Department of Botany and Bacteriology, Ohio Wesleyan University Delaware, Ohio

\section{INTRODUCTION}

Installation of a Sharp CDL-14 Carbon-Dating Laboratory was completed at Ohio Wesleyan University in June, 1962. The unit includes a sample conversion system constructed by Radiochemistry, Incorporated for the conversion of carbonaceous samples to the counting gas, methane. Counting equipment consists of a modified Sharp Low Beta system with a $6 \mathrm{kv}$ power supply and dual printout registers which automatically blank the counting circuits for 0.1 $\min$ for each 100-min printout. The detector has a sensitive volume of $0.5 \mathrm{~L}$ and is housed in a shield consisting of $8 \mathrm{in}$. of lead, $1 \mathrm{in}$. of steel, and $1 \mathrm{in}$. of mercury. Anticoincidence is provided by a cylindrical 2 - $\mathrm{L}$ detector containing 16 anodes and filled with petroleum-generated methane to a pressure of $96 \mathrm{~cm} \mathrm{Hg}$.

Operating pressures for the sample counter range from $76 \mathrm{~cm}$ to $304 \mathrm{~cm}$, depending upon sample size. The background at $76 \mathrm{~cm}$ is $1.56 \mathrm{cpm}$ and at $304 \mathrm{~cm}$ is $1.86 \mathrm{cpm}$. Because of significant variations in count rates obtained from sample preparations of oxalic acid (presumably due to fractionation effects), prepared by wet combustion methods, we have recently switched to 1850 wood. Age-corrected counts on the 1850 wood are statistically indistinguishable from 0.95 times the mean of our oxalic acid count rates. Contemporary standard (1850 wood) count rates show a linear relationship within the range of operating pressures, with a count rate of $4.13 \mathrm{cpm}$ at $76 \mathrm{~cm}$ and $11.89 \mathrm{cpm}$ at $304 \mathrm{~cm}$.

Samples are counted for at least $1000 \mathrm{~min}$ during each of three separate counter fillings. Ages are calculated from comparison with 5000-min background and contemporary standard counts. Background and contemporary standard activities are monitored at weekly intervals to insure stability of the counting system.

All samples are pre-treated with $2 \% \mathrm{NaOH}$ and $10 \% \mathrm{HCl}$. Peat and gyttja samples are pulled down by suction and washed over glass fiber discs and then dried at $105^{\circ} \mathrm{C}$ before combustion. All methane samples are stored for one month to permit decay of radon.

Ages are quoted with a $l \sigma$ counting error, which includes the statistical variation of the sample count as well as that for background and the contemporary standard. The half-life value is $5568 \mathrm{yr}$, and the reference year is 1950 . Check samples, described in more detail in the body of the date list, are given in Table 1 .

The limit of sensitivity for the $0.5 \mathrm{~L}$ detector, based on a counting time of $3000 \mathrm{~min}$ and using the $4 \sigma$ criterion, is $28,750 \mathrm{yr}$ at $1 \mathrm{~atm}$ and $38,750 \mathrm{yr}$ at 4 atm. 


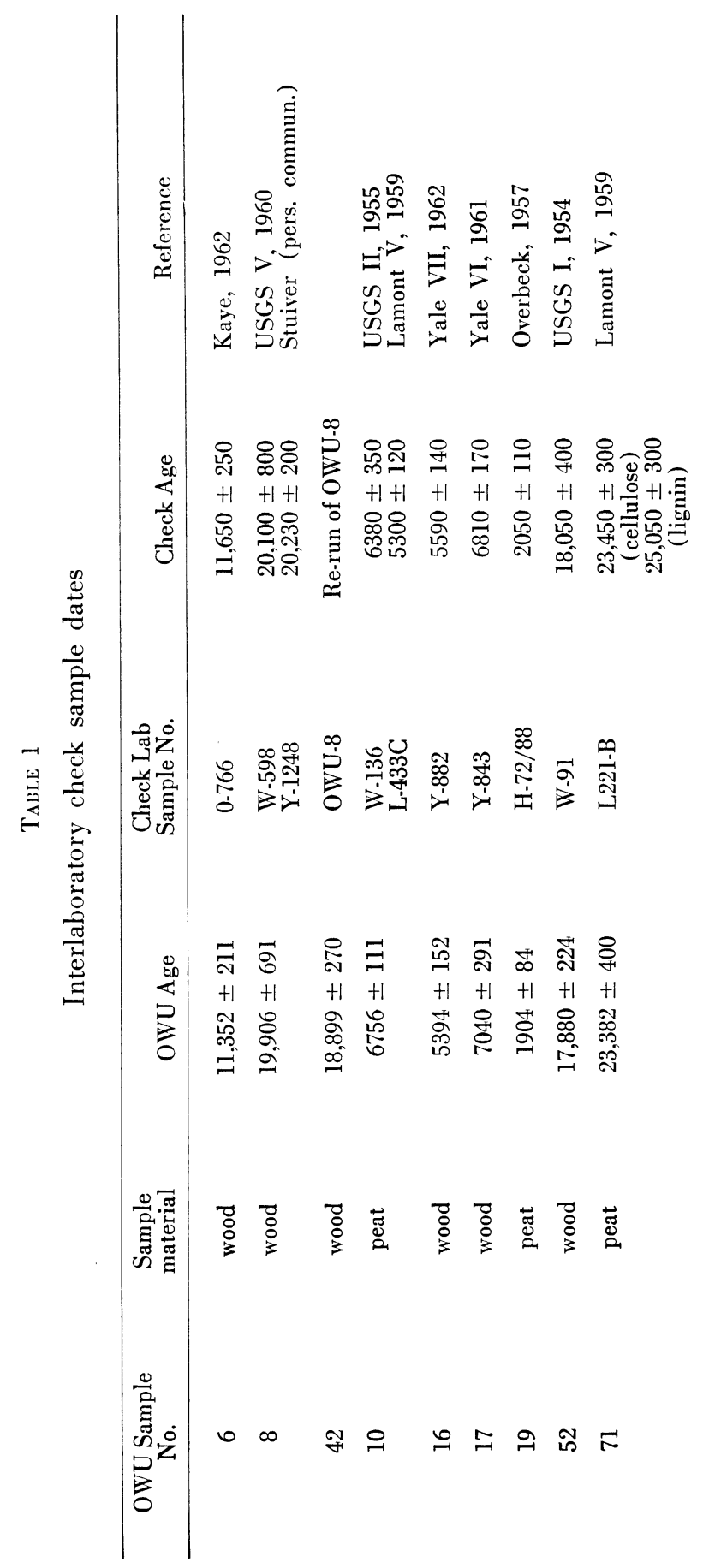




\section{ACKNOWLEDGMENTS}

The support of the National Science Foundation (G21290) for the installation and operation of the equipment is gratefully acknowledged. Thanks are also due to M. Stuiver, W. J. Wayne, W. S. Broecker, and J. L. Forsyth for submitting previously dated samples as checks on the operation of our system. We are indebted to Dr. George W. Burns and Miss Barbara Bruce of Ohio Wesleyan University for identification of the wood samples described in this date list. Finally, the senior author wishes to thank Professor H. Godwin and Dr. Erik Willis of the Cambridge Lniversity Radiocarbon Dating Laboratory and Dr. H. Tauber of the Copenhagen Laboratory for many helpful and stimulating suggestions while he was visiting their laboratories under a John S. Guggenheim Fellowship.

\section{SAMPLE DESCRIPTIONS}

\section{OWU-6. Squibnocket Cliff, Massachusetts}

$11,352 \pm 211$

9402 в.c.

Pine wood (id. by B. Bruce) from a forest bed in a limnic section exposed in a wave-cut cliff on the island of Martha's Vineyard, Massachusetts $\left(41^{\circ} 18^{\prime}\right.$ N Lat, $70^{\circ} 46^{\prime} \mathrm{W}$ Long). Coll. 1960 by C. A. Kaye, L. S. Geol. Survey, and J. G. Ogden, III, Ohio Wesleyan Univ.; subm. by Ogden. Comment: heavergnawed twigs, as well as needles and cones of pine and spruce have been reported by Kaye (1962) from this and several similar sites in SE New England. A similar sample from this deposit was dated by Humble $(0-766)$ at $11,650 \pm$ 250 (Kaye, 1962). A piece of the same $\log$ as OWL-6 was subm. to the Smithsonian Institution (this date list) as an interlaboratory check sample. Their determination (SI-3) is $10,900 \pm 144$. The pollen stratigraphy of this site was discussed by Ogden (1963) in reference to earlier $\mathrm{C}^{14}$ dates reported from the site by the Yale and LSGS laboratories (Yale V; LSGS V). Samples from a similar deposit found at Point Judith, Rhode Island on the 1962 Friends of the Pleistocene Field Conference were subm. and run as OWU.22 (this date list).

\section{OWU-8. Johnson County, Indiana $\quad 19,906 \pm 691$ \\ 17,956 в.с.}

Spruce wood (id. by B. Bruce) from the cutbank of a stream in the SW 1/4. NW 1/4 Sec 30, T11N, R4E (Fruitdale, Indiana 71/2 min quadrangle), about $6 \mathrm{mi} \mathrm{E}$ of Morgantown, $31 / 2 \mathrm{mi} \mathrm{S}$ of Trafalgar, and about $3 / 4 \mathrm{mi} \mathrm{N}$ of the Wisconsin glacial boundary. The cutbank of the stream exposed a veneer (approx. $1 \mathrm{~m}$ thick) of alluvium overlying unweathered calcareous till of $\mathrm{W}$ isconsin age (approx. $80 \mathrm{~cm}$ ), which in turn overlay brown, noncalcareous silt and sand of a buried floodplain sediment (approx. $1 \mathrm{~m}$ thick) that rested upon till with the lithic characteristics of the Illinoian till of this area. The sequence is continuous along the creek bank for a few hundred yards. Wood fragments were abundant in the buried alluvial silt and sand. Sample came from $30 \mathrm{~cm}$ beneath contact with the overlying Wisconsin till. A similar sequence exposed at Trafalgar a few $\mathrm{mi}$ to the $\mathrm{N}$ yielded the following dates from closely similar positions: W-598, 20,100 \pm 800 and W-597, 20,300 \pm 800 (USGS V. 1960). Coll. and subm. by W. J. Wayne, Indiana Geol. Survey. Comment (JGO) : 
pieces of this wood were subm. to the Smithsonian Institution and to Yale University as interlaboratory check samples. The Smithsonian date (SI-4) of $16,513 \mathrm{yr}$ seems quite young, and therefore a second sample was prepared here. See $\mathrm{OWU}-42$, this date list. The determination by the Yale Geochronometric laboratory (Y-1248) gave $20.230 \pm 200 \mathrm{yr}$, which is in good agreement with OWU-8.

\section{OWU-10. Cochrane, Ontario}

Woody peat from a bog exposed on the S side of Highway 11 near Cochrane $\left(49^{\circ} 3^{\prime} \mathrm{N}\right.$ Lat, $81^{\circ} 6^{\prime} \mathrm{W}$ Long), Ontario, about $1.65 \mathrm{mi} \mathrm{E}$ of bridge over Frederick House River. Sample coll. from 1 in. above contact with glaciolacustrine sediments as an interlaboratory check sample near site of W-136 $(6380 \pm 350$; USGS II $)$, and L-433C $(5300 \pm 120 ;$ Lamont V). Coll. 1961 by J. Terasmae and J. G. Ogden, III; subm. by Ogden. Comment (JT) : pollen work done since W-136 and L-433C seems to support OWU determination. The pollen studies are supported by other dates from the region. This date is a minimum age for the drainage of Lake Barlow-Ojibway.

\section{OWU-14. Martha's Vineyard, Massachusetts $\quad 8075 \pm 103$}

White pine cone (id. by G. W. Burns) from $3 \mathrm{ft}$ below surface in a small bog exposed during construction of an access road near town of Gay Head on the island of Martha's Vineyard, Massachusetts $\left(41^{\circ} 18^{\prime} \mathrm{N}\right.$ Lat, $70^{\circ} 46^{\prime} \mathrm{W}$ Long). Coll. 1960 by Mrs. W. Howland, Chilmark, Mass.; subm. hy J. G. Ogden, III. Comment: associated pollen spectra indicated B pollen zone age (7000 to $9000 \mathrm{yr}$ ). Sample run to test possibility that white pine grew on Martha's Vineyard in historic time.

\section{OWU-16. Mesters Vig, Greenland}

Spruce driftwood (id. by B. Bruce) recovered from till-like deposit $\left(72^{\circ}\right.$ N Lat, $24^{\circ} \mathrm{W}$ Long) at Blyryggen, alt $4 \pm 0.5 \mathrm{~m}$. Coll. 1960 by A. L. Washburn; subm. by M. Stuiver, Yale Univ. Comment (JGO) : sample subm. as an interlaboratory check sample. Dated by Yale as Y-882, $5590 \pm 140$ (Yale VII).

\section{OWU-17. Stiles Brickyard, Connecticut}

$7040 \pm 291$

\section{0 в.c.}

Unidentified wood from SE corner of Stiles Brickyard Co. clay pit $\left(41^{\circ}\right.$ $22^{\prime}$ N Lat, $72^{\circ} 53^{\prime}$ W Long). Coll. 1960 by A. L. Bloom; subm. by M. Stuiver. Comment (JGO) : sample subm. as an interlaboratory check sample. Stratigraphy and interpretation described in Yale VI (1961). The age determined by Yale, as Y-843, was $6810 \pm 170$.

\section{OWU-19. Gifhorn, Germany}

$$
1904 \pm 84
$$

\section{A.D. 46}

Peat from $2 \mathrm{~cm}$ above SWK (Grenzhorizont) at Grosses Moore $1 \mathrm{mi} \mathrm{N}$ of Gifhorn, Germany. Coll. 1962 by J. G. Ogden, III, and subm. as an interlaboratory check sample. The relevant dates for this profile are: $\mathrm{H} \mathrm{72/88,0}$ to $2 \mathrm{~cm}$ above SWK, $2050 \pm 110$; and $\mathrm{H} \mathrm{71/85,0}$ to $2 \mathrm{~cm}$ below SWK, $2100 \pm$ 100 (Overbeck et al, 1957). Comment (JGO) : although OWU sample age 
seems to be approx. $150 \mathrm{yr}$ too young, the original exposure was unavailable, and our sample was taken from a peat face approx. $400 \mathrm{yd} \mathrm{W}$ of the original sample locality. In view of the variability of sample dates from recurrence horizons, there is no reason to believe the difference between our date and the Heidelberg date $(\mathrm{H} 72 / 88)$ to be significant.

OWU-21. Delaware, Ohio, Modern Grass $\delta \mathbf{C}^{14}+\mathbf{2 0 \%}$

Modern grass clippings coll. on University Campus $\left(40^{\circ} 18^{\prime} \mathrm{N} \mathrm{Lat}, 83^{\circ}\right.$ $4^{\prime}$ W Long) to determine $\mathrm{C}^{14}$ enrichment due to atomic bomb testing. Coll. May 1962 and subm. by J. G. Ogden, III. Comment: sample is in agreement with values found by Godwin and Willis (Cambridge V) for contemporary samples.

\section{OWU-22. Point Judith, Rhode Island}

$10,906 \pm 112$

Beaver-gnawed pine wood (id. by G. W. Burns) coll. near high tide level, Point Judith beach $\left(41^{\circ} 20^{\prime} \mathrm{N}\right.$ Lat, $71^{\circ} 32^{\prime} \mathrm{W}$ Long), on Friends of Pleistocene Field Conference, May 1962. Macrofossils and pollen spectra closely resemble similar sections described by Kaye (1962), and in particular the Squibnocket forest bed (OWU-6, 11,352 \pm 211 , this date list) described by Ogden (1963).

\section{Blaney Pond series, Naushon Island, Massachusetts}

Finely divided woody peat coll. by Livingstone pistone corer in Blaney Pond, Naushon Island, Massachusetts $\left(41^{\circ} 18^{\prime} \mathrm{N}\right.$ Lat, $70^{\circ} 45^{\prime} \mathrm{W}$ Long). Samples coll. to determine the length of time of the $\mathrm{B}$ pollen zone for this deposit. Pollen studies and additional $\mathrm{C}^{14}$ dates from this core will be used to calibrate the late-glacial and postglacial pollen sequences of the offshore islands of SE New England (Ogden, 1963). Coll. 1962 and subm. by J. G. Ogden, III.

\section{OWU-27. BP 1.11-1}

$8108 \pm 105$

6158 в.c.

Upper part of B pollen zone just below rise in oak pollen curve. Sample from 9.90 to $10.02 \mathrm{~m}$.

OWU-28. BP 1.11-2

$9482 \pm 319$

7532 в.c.

Lower part of B pollen zone just above spruce decline. Sample from 10.44 to $10.54 \mathrm{~m}$.

\section{Gray's Lake series, Gray's Lake, Illinois}

Clay gyttja from a sediment core coll. with a 1.5 in. Livingstone piston sampler in Gray's Lake, Lake County, Illinois $\left(42^{\circ} 20^{\prime} \mathrm{N} \mathrm{Lat,} 88^{\circ} 3^{\prime} \mathrm{W}\right.$ Long). Pollen stratigraphy is being studied by P. B. Sears, Yale Univ. Coll. 1961 by P. B. Sears and J. G. Ogden, III; subm. by P. B. Sears.

OWU-33. GL-1 : 313

$4003 \pm 97$

Stiff clay gyttja from 8.70 to $8.82 \mathrm{~m}$. 
OWU-34. GL-1 : 314

$6539 \pm 97$

Marly clay gyttja from 9.92 to $10.08 \mathrm{~m}$.

4589 в.c.

OWU-42. Johnson County, Indiana

$18,899 \pm 270$

16,949 в.C.

Re-run of OWU-8 (this date list) following Smithsonian Institution date of 16,513 (SI-4). Comment: although OWU-42 is younger than the original determination of OWU-8 (19,906 \pm 691$)$ we attribute this to a small leak in our methane reactor which has since been rectified. The difference between the two OWU determinations is not significant.

OWU-51. Mound City, Ohio

$1772 \pm 53$

A.D. 178

Charcoal from Mound 10 Feature 12A Mound City Group National Monument $\left(39^{\circ} 22^{\prime} 35^{\prime \prime} \mathrm{N}\right.$ Lat, $83^{\circ} 0^{\prime} 10^{\prime \prime} \mathrm{W}$ Long). Sample from charred layer beneath sub-floor cremation which included one cord-marked pottery sherd with a copper headdress and copper adze resting on top of the layer. Coll. 1963 and subm. by R. S. Baby, Ohio State Mus., Ohio State Univ. Comment (RSB) : date fits with Hopewellian artifacts characteristic of site.

\section{OWU-52. Bier's Run, Ross County, Ohio $\quad 17,880 \pm 224$ 15,930 в.c.}

Spruce log (id. by B. Bruce) projecting from till bank along Bier's Run in Ross County, South Union Township, $5.5 \mathrm{mi} \mathrm{NW}$ of Chillicothe, Ohio. Overlain by $2 \mathrm{ft}$ of fine sand and $3 \mathrm{ft}$ of till. Coll. 1963 and subm. by J. L. Forsyth, Ohio Geol. Survey. Comment: sample run as interlaboratory check sample. Previous sample from this locality, W-91, gave 18,050 \pm 400 (USGS I).

\section{OWU-53. Black Lake, Logan County, Ohio}

$10,558 \pm 365$ 8608 B.c.

Clay gyttja from sediment core BL-2 coll. with a Livingstone piston sampler in Black Lake $\left(40^{\circ} 16^{\prime} \mathrm{N}\right.$ Lat, $83^{\circ} 54^{\prime} \mathrm{W}$ Long). Sample depth from 7.00 to $7.10 \mathrm{~m}$. Comment: sample, like the Silver Lake, Ohio series (this date list) is part of a general research program into the sedimentation rates, pollen and $\mathrm{C}^{14}$ stratigraphy of lakes in Ohio by Ogden. Although additional dates and the pollen stratigraphy of this deposit will be published subsequently, this date is included because it dates the replacement of spruce by oak in this part of Ohio. See also Silver Lake series, OWU-39, this date list.

\section{OWU-59. Homolka Hut T, Kladno County, $\quad 3424 \pm 185$ Czechoslovakia \\ 1474 B.C.}

Charcoal from $1.5 \mathrm{~m}$ deep in the deposits of Hut $\mathrm{T}$, a late unit at the site of Homolka, village Stehelčeves, Kladno County, $11 \mathrm{mi}$ WNW of Prague, Czechoslovakia. This is a fortified hilltop village site of the Rivnač culture, Eneolithic period, with sparse Early Bronze Age (Unětice) material apparently overlying the Eneolithic deposits at this point. The foundation of the pit was cut into the slope of the hill and contained Eneolithic material only. The overlying stratum contained a mixture of Řivnač and Early Bronze Age wares and the traces of a Bronze Age house. Sample comes from the Eneolithic deposit. 
Coll. 1960 by E. Pleslova; subm. by R. W. Ehrich. Comment (RWE) : see OWU-60.

\section{OWU-60. Slanska Hora, Czechoslovakia}

Charcoal from site of Slanska Hora at Slany, $18 \mathrm{mi} \mathrm{NW}$ of Prague, Czechoslovakia. Like OWU-59, this comes from a fortified hilltop Eneolithic settlement of the Rivnač culture (Pit 4). Coll. 1960 by V. Moucha; subm. by R. W. Ehrich. Comment (RWE) : since these dates are considerably younger than the presumed archaeological date (which has an established relation to $\mathrm{C}^{14}$ dates of earlier and later periods in neighboring territory), the samples must either be contaminated or stem from a context later than the Eneolithic (Řivnač) age claimed for it.

\section{McGraw series, Chillicothe, Ohio}

Charcoal from a Hopewell village site located $1 \mathrm{mi} \mathrm{S}$ of Chillicothe, Ohio $\left(39^{\circ} 18^{\prime} \mathrm{N}\right.$ lat, $82^{\circ} 59^{\prime} \mathrm{W}$ Long). Site includes fruits and nuts of hickory, walnut, acorn, hackberry, and wild plum, in addition to two races of corn. Coll. and subm. by O. H. Prufer, Case Inst. of Tech., Cleveland, Ohio. Comment (OHP) : samples are from a Hopewell midden, which is culturally homogeneous (as is the entire site). The midden was overlain by an average of two $\mathrm{ft}$ of flood deposit composed of two distinct layers. Ceramic affiliations indicate a late classic Hopewell occupation. The dates are acceptable.

OWU-61. MeGraw Unit C-1

\section{OWU-62. McGraw Unit D-2}

\section{Silver Lake series, Logan County, Ohio}

Gyttja from sediment cores SL-1, SL-2 and surface sample core SL-3, taken with a $1.5 \mathrm{in}$. Livingstone piston corer in $11.6 \mathrm{~m}$ of water in the $\mathbb{W}$ basin of Silver Lake $\left(40^{\circ} 21^{\prime} \mathrm{N}\right.$ Lat, $83^{\circ} 48^{\prime} \mathrm{W}$ Long), $7 \mathrm{mi} \mathrm{W}$ of Bellefontaine, Ohio. Samples were measured as part of a research program into sedimentation rates in hard- and soft-water lakes. Pollen stratigraphy and carbonate analyses of the lake sediments are reported in Ogden (in press). Depths are corrected for slight compaction during extrusion. Coll. by J. G. Ogden, III.

OWU-72. SL-3:1 Surface 0-10 cm, Marl $829 \pm 62$

$\mathrm{Marl}, \mathrm{CO}_{2}$ generated by hydrolysis with $\mathrm{HCl}$.

OWU-72A. SL-3:1 Surface 0-10 cm, Organic

Same as OWU-72, but organic fraction.

OWU-30. SL-2: 257-1 Surface 0-10 cm, organic $1186 \pm 161$

Organic fraction at surface of core SL-2.

Comment: because this lake is located in a region of limestone-rich till, it was expected that sample ages would be "too old" by an amount proportional to the amount of Paleozoic carbonate in the lake system. Further studies are in progress by means of which both $\mathrm{C}^{14}$ dating and pollen stratigraphy will be 
used to cross-calibrate sediment cores from this and other lakes in Ohio, from both hard- and soft-water areas. As a consequence of the surface sample ages listed above, the remaining dates in this list are presented with a correction of $1200 \mathrm{yr}$ as an initial estimate of "old" carbon dilution.

OWU-38. SL-2: 257-4 60-70 cm, organic

$106 \pm 100$

Sample from sharp rise in Ambrosia curve, marking introduction of European agriculture.

OWU-47. SL-2 : 260-4 $130-140 \mathrm{~cm}$, organic

Sample from 2d Fagus pollen maximum.

OWU-77. SL-2: 261-4 $210-220 \mathrm{~cm}$, organic

Sample from base of $2 \mathrm{~d}$ Fagus pollen maximum.

OWU-57. SL-2: 264-2 $400-410 \mathrm{~cm}$, organic

Sample from top of 1st Fagus pollen maximum.

OWU-58. SL-2: 265-4 500-510 cm, organic

Sample from base of lst Fagus pollen maximum.

OWU-39. SL-2: 254-1 605-615 cm, organic
$1090 \pm 423$ A.D. 860

$3833 \pm 217$ 1883 в.c.

$4095 \pm 232$

2145 в.c.

$9588 \pm 210$

7638 в.c.

Sample from spruce-oak transition in Silver Lake. Final disappearance of Picea pollen, and sharp rise in Quercus, Carya, and Ulmus pollen.

\section{OWU-71. Dashwood Cliff, Vancouver Island, $\quad \mathbf{2 3 , 3 8 2} \pm 400$ British Columbia \\ 21,432 в.c.}

Peat from the base of the Quadra sediments exposed at Dashwood $\left(49^{\circ}\right.$ $22^{\prime} \mathrm{N}$ Lat, $124^{\circ} 31^{\prime} \mathrm{W}$ Long) near Qualicum Beach on Vancouver Island, British Columbia. Coll. 1953 by J. G. Fyles and subm. by W. S. Broecker as an interlaboratory check sample. Age determination by the Lamont Geological Observatory gave the following ages on chemical fractions; L-221B: peat cellulose, 23,450 \pm 300 and L-221B: peat lignin, 25,050 $\pm 300 \mathrm{yr}$ (Lamont V). Comment (JGO): because of the small sample size, the whole sample was burned after pretreatment with $\mathrm{NaOH}$ and $\mathrm{HCl}$. The OWU date is in excellent agreement with the Lamont determination.

Date lists:
Cambridge IV
Lamont V
USGS I
USGS II
USGS V
Yale V
Yale VI
Yale VII
Yale VIII

\section{REFERENCES}

Godwin and Willis, 1961

Olson and Broecker, 1959

Suess, 1954

Rubin and Suess, 1955

Rubin and Alexander, 1960

Stuiver, Deevey and Gralenski, 1960

Stuiver and Deevey, 1961

Stuiver and Deevey, 1962

Stuiver, Deevey, and Rouse, 1963

Godwin, H., and E. Willis, 1961, Cambridge University natural radiocarbon measurements

IV: Radiocarbon, v. 3, p. 77-80. 
Kaye, C. A., 1962, Early postglacial beavers in southeastern New England: Science, v. 138, p. $906-907$.

Ogden, III, J. Gordon, 1963, The Squibnocket Cliff peat: radiocarbon dates and pollen stratigraphy: Am. Jour. Sci., v. 261, p. 344-353.

Ohio A radiocarbon-dated pollen sequence from Silver Lake, Logan County, Ohio: Ohio Jour. Sci., in press.

Olson, E. A., and Broecker, W. S., 1959, Lamont natural radiocarbon measurements V: Radiocarbon, v. 1, p. 1-28.

Overbeck, F., Münnich, K. O., Aletsee, L., and Averdieck, F. R., 1957, Das Alter des "Grenzhorizonts" norddeutscher Hochmoore nach Radiocarbon-Datierungen: Flora, v. 145 , p. $37-71$.

Rubin, M., and Alexander, Corinne, 1960, U. S. Geological Survey radiocarbon dates V: Radiocarbon, v. 2, p. 129-185.

Rubin, M., and Suess, H. E., 1955, U. S. Geological Survey radiocarbon dates II: Science, v. 121 , p. $481-488$.

Stuiver, M., and Deevey, E. S., 1961, Yale natural radiocarbon measurements VI: Radiocarbon, v. 3, p. 126-140.

262. 1962, Yale natural radiocarbon measurements VII: Radiocarbon, v. 4, p. 250.

Stuiver, M., Deevey, E. S., and Gralenski, L. J., 1960, Yale natural radiocarbon measurements V: Am. Jour. Sci. Radioc. Supp., v. 2, p. 49-61.

Stuiver, M., Deevey, E. S., and Rouse, I., 1963, Yale natural radiocarbon measurements VIII: Radiocarbon, v. 5 , p. 312-341.

Suess, H. E., 1954, U. S. Geological Survey radiocarbon dates I: Science, v. 120, p. 467-473. 